\title{
NEO-ZIONIST FRONTIER LANDSCAPES IN THE OCCUPIED TERRITORIES
}

\author{
Izhak SCHNELL, Ben-Israel ARNON \\ Tel Aviv University, Israel
}

\begin{abstract}
Immediately after the 1967 war and the occupation of the West Bank and Gaza the national religious youngsters (Gush Emmunim settlers) reached out to settle the new frontier of the biblical places. By thus, they have developed a Messianic myth. The interpretation of Gush-Emmunim settlers' experience of landscapes reveals a complex and contradictory structure of sense of space. Settlers' mythical sense of space may be understood in two strata - imagined and material. The imagined stratum is conceived mainly in transcendental romantic terms while the material is reified according to classic conceptions. Two main contradictions are outstanding: first, between the romantic representation of Jewish landscapes and the classic representation of Palestinian landscapes in the imagined stratum; second, between the romantic representation of the Jewish home space in the imagined stratum and the classical representation of the suburban Jewish home landscape in the material stratum. The first contradiction is inherent in frontier societies as a means to pseudo-rationalize the colonisation of the land, although in general there may be a mixture of romantic and classic attitudes towards the natives. The settlers pioneering myth is highly subsidised by the government and aggressively backed by military force. This enables them to tolerate the surrounding fear, antagonism and hatred. Thus, the landscape they build represents power and domination with no regard to local nature and to the Palestinian landscapes that are perceived by the settlers as part of it.
\end{abstract}

Key Words: colonization, frontier societies, Romantic and Classis visions of human-nature synergy

\section{Introduction}

Shortly after the victory over the Arab countries in June 1967, groups of national religious youngsters started to settle the Biblical Jewish territories, namely the newly occupied territories formerly controlled by Jordan, on the West Bank ${ }^{1}$. The messianic national religious GushEmmunim movement was one of the leading groups to respond to the divine call to colonise the new frontier, sometimes even contrary to government decisions (Newman 1985, Galili 1993). Although the movement was small during the seventies, it managed to force the Labour government to start the settlement process and it gained strong influence over rightist governments in later years. Kemp (1991) explains that it has attracted the imagination of many Israeli supporters because the frontier culture has remained a major ethos of Zionist ideology even after Zionism agreed to compromise over limited boundaries. Thus, colonising the occupied territories may be viewed as a new wave of frontier expansion, following several prior to independence (Kemp 1991, Aran 1986, De-Shalit 1995, Biger 1997).

In the year 2010, about three hundred thousand settlers live in the Occupied Territories in addition to about 250,000 in territories annexed by greater Jerusalem. About 40,000 of them

1) The term is used popularly to describe the area of Mandatory Palestine west of the River Jordan that was occupied by the Kingdom of Jordan in 1948. 
are direct supporters of the movement, which has evolved into settlers' organisation. About fifty thousand more settlers support the national religious movement but adopt a less extremist ideology than the former Gush-Emmunim members. The rest are either secular or UltraOrthodox who have settled the Occupied Territories to acquire larger suburban houses cheaply. Our research focuses on the national religious settlers and the main ideological engine behind them-the members of the Gush-Emunim movement that had disseminated in the settlers' council.

The movement adopted a fundamental mythical religious worldview, which has succeeded in challenging the social democratic version of Zionism after the crisis of the 1973 Yom "Kipur war" (Newman 1985). Founded in 1974 as an anti-establishment movement, it received legitimacy after the rise of the rightist government in 1977 (Feige 1999, 2002). Jewish colonisation of the Palestinian frontier may present a live laboratory of the tension between the dream of returning to the local nature of the Holy Land in order to reborn from it as new Neo Zionist Israelis who view religious Judaism as the core of that new identity (Gurevitz 2007) and the practical building of middle class suburbs that are alien to local nature.

The purpose of the following paper is to highlight the discrepancy between their vision of constituting a neo-Zionist identity by settling close to the Holy Land natural environment and the suburban landscape that turns its back on the local nature being built by them. We argue that this discrepancy stems from tensions between the romantic and the classic views of human-nature synergy that guided the imposition of Israeli upper-middle class conventions on the local landscape. This includes the imposition of suburban landscapes that meet the dreams of the Israeli upper-Middle classes and do not fit into the Palestinian perception of local nature and $t$ landscapes, in a way that what Baruch Kimmerling (1983) has described as "limited frontier", as savage, untamed spaces. We contend that these tensions are largely inherent in the frontier culture and may be comprehended, when comparing romantic (A world view that assign nature and life close to nature priority) with classic (A world view that assign civilization and life far from nature priority) interpretations of the human-nature synergy.

We present the argument in three sections following a conceptual introduction. The first unravels the romantic aspects of the colonisation narrative and the second its classic aspects. The third section highlights the contradictions between the two and the inconsistencies between the romantic visionary conceptions of these landscapes and their classic material appearances.

\section{Conceptual Framework}

Conflicts between settler and native societies are inherent to frontier colonisation. They are perceived as challenging both the establishment of settler societies and a moral stance towards native societies (Turner 1963, Hasson 1981). David Sibley (1995) widens the argument to any society of "others", which may evoke feelings of hostility and anxiety on the one hand and envy and desire on the other. He conceptualises the frequently mentioned argument concerning the ambivalent attitude toward others - savage and immoral on the one hand and exotic and representing natural and innocent lifestyle on the other. The author argues that segregation is intended to reduce anxiety while raising romantic attitudes toward others although, as he shows, segregation may achieve the opposite results. However, this ambivalent attitude is frequently mentioned in the context of pioneering societies. Turner's narrative best represents the problem. In his model, wild nature reshapes the pioneers into new human beings who from their own side reshape nature and vice versa. Schama (1955) has best commented on the mutual transformation of nature and cultural landscape in the consolidation of nation states. 
A romantic approach to human-nature synergy treats settlers' pioneering process, as life close to nature and if possible, in the old motherland, which may revive national life and civilisation while natives are perceived to be innocent pure people well rooted in the local nature (Anderson 1991, Passi 1999). Romantic perceptions of human-nature synergy view nature as a major source of emotions, inspirations and creativity. In nature, people may find clues for rules of harmony, symmetry and proportions as well as for mystery, astonishment and splendour (Sinha 1995). Hence, nature becomes the main source of ethical and aesthetic values and life close to nature is associated with a "good life". In particular, sensual experience and belief that natural, wild human instincts, intuitions and emotions express life's natural drama characterises the romantic worldview. Anachronistic nostalgia for ancient history, when human life was close to nature, is understandable, in this context. Thus, recreating the golden age in the motherland may be perceived as a means to regenerate national identity (Anderson 1997, Ploszajska 2000), even if this is by adopting selective, distorted narratives (Naula 2000, Schnell 2001). Worldviews that guided the preservation of national parks in the U.S.A. viewed Nature as the representation of God, and fusion with God-Nature as an experience of spiritual clarification (Cronon 1995) that may symbolise the return to the "Garden of Eden" (Marchent 1995).

Gush-Emmunim represents a shift in religious Zionist theology from the panentheist doctrine that God includes and interpenetrates the universe while being more than it, to pantheism, which perceives God and Nature to be inseparable. Consequently, Gush-Emmunim now maintains that the holiness of the Holy Land is immanent in the stones and soils of the Land itself (Schwarz 1996, Ravitzki 1998). In the context of the frontier, mystification of nature may serve to glorify the pioneering action - the power of nature to mould a new human being, a wild and noble creature simply innocent and courageous, on the one hand, and the heroic victorious battle of that human being against wild nature associated with savage man on the other hand. This means that the frontier pushes the pioneers into a human - nature synergy from which nature and human beings are expected to be structured and restructured while performing a dramatic and heroic struggle to recreate harmony with nature (Schnell 1997, 1998, 2000). Natives are perceived as authentic unspoilt representatives of local nature, innocent creatures on which the pioneering society may model itself (Dijkink 1996).

A classic view of human-nature synergy treats the settlers as civilized people who impose their order and discipline on frontier landscapes bringing progress to the bewildered frontier (Sinha 1995, Marchent 1995). Culture and Nature are perceived in the case of the American frontier as opposite extremes of a hierarchy with civilised culture at the apex and savages at the base (Light 1995) . Similar ideas dominated deterministic environmental theories such as nineteenth century colonial beliefs (Sibley 1995). Accordingly, human beings become the main source for ethical and aesthetic values, and life in towns with geometrically designed gardens is associated with the ideal of "a good life". Human proportions and symmetries are the key sources of aesthetic criteria, and human rationality is accepted as the main legitimisation for action.

By the same token American suburbs may be described as classical representations of humannature synergy. Being described as disciplined forms embedded in social discourses, which are influenced by British aesthetic (Jenkin 1994, Mitchel 1994, Schein 1997) they impose on nature human order. Above all, they reflect the discourses of individualism, family lifestyle and tight communal life (Davidson 2006). It is not my intention to enter into details in describing the American suburb beyond its characterization as a classic landscape in which the discourses of single family houses with middle classes obsession to well cared gardens, rich with lawns and imported trees and in which households invest their identities as 'perfect consumers of middle 
class communities.

In the context of the frontier, nature is perceived to be wild and dangerous, manageable only by very determined and technologically superior struggle. Similarly, the savage native populations are perceived to make no attempt to improve the land, and thus to have no moral right to it. Therefore, they are alien to all moral and aesthetic codes (Cronon 1999). Only by accepting the settlers' civilised culture may they gain moral legitimacy and avoid destruction (Marchent 1995, Light 1995). Demonising the wilderness of nature and of savage man as part of it, serves to legitimise and add distinction to the pioneers, who are perceived as bringing progress to both settlers and natives (Ploszajka 2000, Kimmerling 1983, Schnell 1997, 1999). Furthermore, while the pioneering process is perceived in divine concepts, savage men who are part of nature, have no part in the divine process. In many cases, this distinction is the source of racist ideas (Brody 1983, Leter 2002), articulated to its' extreme in the case of South African Apartheid worldview (Dreper 1998). Michael Fiege $(1999,2002)$ presents the same argument in his study of Gush-Emmunim without articulating it in terms of romantic and classic terms. He demonstrates romantic aspects in their sense of closeness to God and nature adopting a pantheistic worldview, which may lead to the rebirth of the Jews as well as nature, the use of the Bible as a historical document, interpretation of the landscape and archeological sights in the light of clues from the Bible and representation of the Palestinians as savage. Others emphasise the fundamentalist character of the movement (Sivan 1991), which claims to promote Jewish particularistic identity (Aran 1986) and to save Jews from the corruption of Western cultures (Shafat 1995). They believe that suburban settlements may erase the 1967 boarders creating a new Neo-Zionist reality in which the Palestinians will loose grasp on the Land (Newman 2001). As a fundamental movement they speak in the name of a divine order that other people so far fail to grasp, therefore they believe they have a historical responsibility to take the lead (Sprinzak 1991).

In this study we intend to focus on the romantic-classic dilemma in constituting landscapes, arguing that the romantic vision of constituting a neo-Zionist identity by a new wave of naturecultural landscape dialectic ended up by the constitution of a classic suburban landscape. Such political struggles between the two worldviews appear in one way or another in all pioneering societies including the American and the early Zionist ones (Cronon 1999, De-Shalit 1995). But it seems that the split between the romantic vision and the classic reality has never been so wide.

The present study employs an interpretative methodology that makes it possible to examine memoirs, political articles, geographical representations and art in a broader frame of reference and to identify events that typify it. This paper is sourced from memoirs and political essays and from cartographic maps, photographs and art paintings calling for double hermeneutical interpretation. The use of heterogeneous means of communicating settlers' interpretations is expected to overcome the argument that semiotic interpretations are not intrinsic to the landscape but are mediated by a community of interpreters. Therefore, we focus our investigation on testimonies to settlers' interpretations, hoping that different expressions of cartographic, artistic and verbal interpretations complement each other and expose sets of meanings adopted by wider segments of the settlers' community. In the article each source helps to verify the validity of other sources while spreading some new light on the issues discussed enriching the interpretation. Although the original study examined copious data, we have chosen to present here a limited number of sources that we believe reflect the spirit of perceptions that the settlers have institutionalised and are broadly manifested in their society.

Authors of interpretative texts derive their world of images and meanings from the socio-cultural 
and political milieus in which they operate, and play an important role in constructing the social reality of these milieus (Bell Hooks 1991). The process of constructing a double hermeneutic theory entails a dialogue between possible exegetic patterns and the text, in the course of which the author's original narrative is converted into interpretative text. We believe that interpretations of the settlers' landscape perception in the romantic and the classic traditions of understanding human and nature synergy may best highlight the aforementioned contradictions in the settlers' perceptions.

\section{Transcendental Romantic Frontier Landscapes}

The following analyses idealisations - texts, paintings, maps and photographs - in a romantictranscendental narrative of the return to the ancient Eretz-Israel landscape. Texts representing romantic perceptions of nature and surroundings appeared in newspapers, literature and Internet sites identified with Gush-Emmunim. Hanan Porat, one of Gush Emmunim's original leaders, describes the return to Gush-Etzion ${ }^{2)}$ after the six-day war.

We debussed at the foot of the solitary tree and walked up the old winding path to Kfar-Etzion. We were a long piebald line, middle-age grey mingling with the black and gold of teenagers in their first ascent. There on the skyline crouched Harei Hebron ${ }^{3)}$ covered in a bluish mist ...the excitement of opening a dusty, faded album of childhood memories hidden somewhere raised goose flesh. Kerbstones on either side of the road among the sand, low trailing vines, quivering golden stalks and clods of hillside earth bore silent witness against loud-mouthed journalists: "the land is very good indeed"' (Porat 1988).

In the narrative, replete with emotion but without pathos, Porat does not describe his own 'childhood memories' but the stories that he has heard. By anthropomorphising various components of the landscape, he imbues nature and the surrounding landscape with an active role in the homecoming devoid of heavy historic-national baggage. The description is free from organised, ideological idiom, although the 'middle-aged grey' and 'the childhood memories' hint at the one-time Kibbutz, the battle and the evacuation. 'The land is very good indeed' ignores barren wilderness and challenges sceptics evoking the words of Joshua and Caleb '... an exceeding good land' recalling the Biblical conquest and settlement. Natural, legitimate association with the place derives from previous acquaintance with the surroundings and the Kibbutz's recent existence rather than from ancient traditions, reference to which is, therefore, limited. 'Homecoming' is the central element in Porat's narrative, rather than the intimacy with the environment that is usually distinctive of the romantic approach. The Kibbutz renews historic links with the landscape, and from the national angle, a people returns to its homeland.

The Gush-Etzion regional council published a homecoming song,

We return to our home, to fields of blood and glory.

The mountain has become a legend and its warriors, lions.

Etzion, Etzion, our mountain of light and Sabbath,

Your memory lives in our hearts; you will never fall again.

This is a pledge too much more than a geological formation, endowing the mountain with personal status. The commitment not to abandon it again evokes the Zionist symbol of Massada, 'Massada shall not fall again'. Thus the national legend becomes a personal experience and

2) Bloc of Jewish settlements west of Hebron lost to the Jordanians during the war waged by Arab nations against the nascent Jewish State. 
gives rise to the feeling that the interruption of Jewish settlement occurred in their lifetime. This granted the ethos of return an apparently rational, understandable dimension. The heroic motif here is particularly important in Zionist Romanticism (Gorney 1966, Shapira 1992).

Another article appraises the settling of Sebastia demonstrating that it fits one of GushEmmunim's most important myths. Here, the element of 'return' is mainly theoretical, for the surroundings are entirely unfamiliar. Beside human heroes, considerable significance attaches to natural phenomena, which acquire mystic-spiritual dimensions. Initially, nature frowns and challenges; cold, damp, wind and dirt toughen, refine and elevate the spirit, essential for achieving the great dream. As the settlers' foothold consolidates, nature's status adapts to collaborate in the settlement process,

The dust that whitens your clothes becomes a partner. Originally it was dirt, but now it is the beloved soil of Eretz-Israel that you merge with. How pleasant ... the Morning Prayer, the blue sky. You breathe the fresh morning air. What can be more suitable than being part of surrounding nature and singing with it? ('Love of Ancient Time' Nekuda 102, p. 49)

Thus, God, man and nature join to accompany the homecoming.

Further support for the transcendental messianic-redemption dimension of the narrative appeared one year after the first Intifada, under the headline 'Latest Tidings of GushEmmunim'. These described preparations to establish a new settlement south of Hebron, which it defined as spiritual, religious assignments to return the people to the Land, Nature and Torah and become close to Heaven and Earth (Nekuda 122). The act of settlement is self-liberating, religious rehabilitation that purifies the return to mother-earth.

In many of their Internet sites and elsewhere, Gush-Emmunim settlers express their ideology by emphasising the unbroken historical continuity between their settlements and locations of past Jewish activity. Settlements' names like Beit-El Anatot and close to half of the settlements' names are rooted in the Bible and are followed by an attempt locate the Biblical place at the same location (Schnell, 2011). Undeniably there is much covert selectivity and spatial manipulation in this. Nevertheless, introducing past splendour in the current environmental narrative enhances its Romantic nature - not invasion of alien space but return to ancestral lands, enabling one to re-enact different Biblical stories from one's veranda.

The Samaria district council declares that its settlements are near ancient First and Second Temple sites, or those from the Mishnah and Talmud periods (Slonim 1998). The historical context validates the settlement ideology and highlights the resurrection of ancient Samaria. The Gush-Emmunim settlers' romantic-transcendental environmental narrative is one of return to the landscapes of indomitable forefathers; a narrative of the symbolism and legends of national heroism spatially integrated with spiritual rehabilitation and return to Nature.

The following is a short review of paintings by Gush-Emmunim settler artists that display similarity and a common outlook. It aims at better understanding their romantic perception of the landscape. Their work supports the environmental-romantic narrative at another cultural level, representing both very profound socio-cultural perceptions and simultaneously moulding environmental outlooks in the public discourse. Initially, Shmuel Moshannik's painting, 'Judean Fields', seems to depict a peaceful, rural landscape. However, an air of mystery derives from the hazy horizon, the vanishing path at the centre and traces of ancient lifestyles - terracing, olive trees, path - but whom does all this belong to? 
Baruch Nachshon's serene, imaginative, flawless landscapes reveal a similar romantic nostalgia for Biblical times and consensus with the outside world. Ancient architecture - domed roofs and minarets, and figures wearing skullcaps and ritual fringes, and sounding the shofar ${ }^{4)}$ communicate the artist's perceptions of our forefathers' landscape. A strong messianic - light envelops everything, reminiscent of Diaspora painting styles, light, without shadow, divinely absolute (Hirschfeld 1989). The artist claims that he paints a future messianic experience rather than past or present. Nonetheless, his aesthetic-idealistic world romanticises the local landscape and integrates with it.

A similar atmosphere pervades Nachman Rechel's work that says he paints ethno-messianic events that appear to occur in Eretz-Israel. 'The Jordan', seemingly a conventional landscape, is charged with ethnic meaning. He writes, 'The ancient river's flow forever alternates between shade and light, times of darkness and light for Israel.' Time is indefinite in his work; landscape and aesthetics are ancient but the messianic vision is futuristic, dissociated from current Israeli experience. Light is mystically divine. Water expresses God's holy, pure gift.

Three other paintings represent Israel's homecoming to the awaiting, unpopulated wilderness, which thus acquires a messianic radiance.

'Templewards' evokes the Temple, diffusing a golden light, as the cynosure in an idealistic, soul-inspiring landscape. The spellbound gaze of shepherd and flock towards it highlights the messianic theme. The shepherd presents the desired, authentic lifestyle.

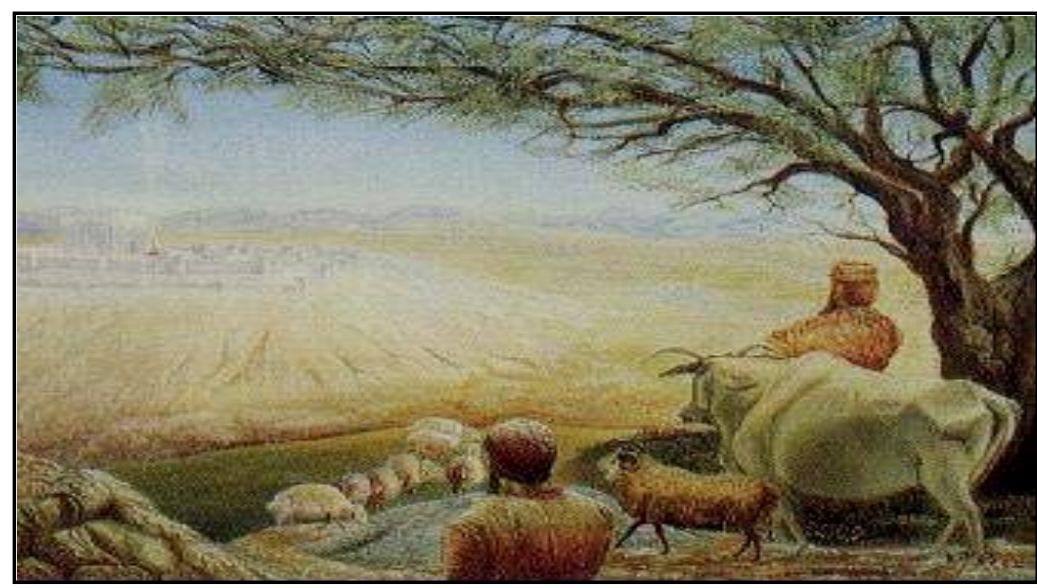

Fig. 1 - Rechel, A messianic vision of the new exodus

In Rechel's 'Grace after Meals', the Temple Mount at the wilderness' centre emphasises the divine connection with the earth. He explains that this is how all Jews imagine Jerusalem. At the bottom of the painting 'The Seven Fruits' of Eretz-Israel ${ }^{5)}$ appear with the prayer-book open to show the second paragraph of the eponymous prayer ${ }^{6)}$. The 'land of goodness and delight' is

4) A ram's-horn trumpet used by Jews in religious ceremonies and as an ancient battle signal.

5) Wheat, barley, vines, fig-trees, pomegranates, olive-trees and date honey. Deut. 8.8.

6) Commencing with the words, 'We thank you Lord God for the land of delight and goodness that you have endowed us... 
available for Jews who will come to trust in its holiness and enjoy its fruits.

Cartographical expressions of space may imply ethnic interpretations of surrounding landscape. The supporters of the Lev Ha-Aretz tourist authority mainly tend politically towards Gush-Emmunim. The frontispiece of their map, 'Heart of the Bible Land', presents a very symbolic picture of Eretz-Israel, with the curving Mediterranean coast in the West, and the greenery and dramatic, romantic profusion of Jordan waters in the North. The camel and historical figures surrounded by well-preserved ancient sites in the centre represent the Biblical past. The locally produced Jeep represents the present. The title specifies an environmental experience deriving directly from the romantic, Biblical world of aesthetic imagery.

The map highlights history. The Palestinian controlled 'A' areas ${ }^{7)}$ appear as obscure yellow patches, Palestinian villages and towns are absent, excepting Bethlehem and Hebron, which have Biblical, Jewish associations. Contrastingly, Gush-Emmunim settlements appear conspicuously as small, red-roofed, rural houses with garden and tree. Frontispiece and map contribute to the romantic narrative mainly in the temporal dimension. Fantasy exists outside time. It emphasises the narrative's irrational aspects, incorporating heroic past, pastoral present and future messianic absolution to influence the apprehension of reality.

While romantic-transcendentalism appears ubiquitously in texts and paintings identifiable with Gush-Emmunim, surprisingly little in the actual scenery of their settlements is attributable to such perspectives. However, some examples do appear in the religious buildings that dominate settlements of those conforming to religious tradition ${ }^{8)}$.

Unadorned stone-covered arches surround the Othniel Torah Study House's entrance, resembling a classic archaeological but environmentally appropriate site. The presence of palms, more suitable in the coastal plain, symbolises folkloristic authenticity. The surrounding lawns indicate significant expenditure, but represent another aesthetical style.

Moshav Gadid's synagogue is pictured on the Internet. The arch-adorned windows surrounding the building and the polygonal outline with a small dome rising from the roof's centre are oriental elements. Here, too, the palm has more than ornamental meaning; its fruit, height and symmetry symbolise the positive for Jews. Although less important than the olive or vine, it is included among the aforementioned 'Seven Fruits'. Since the dawn of Zionism it has expressed Jewish roots in the East. Furthermore it became the symbol of orientalist images among Jews in Diaspora. Similar styles are evident in religious buildings in other Gush-Emmunim settlements.

Unlike other romantic approaches that display some admiration for indigenous culture, the settlers' romantic narrative reveals no empathy with Palestinian representatives of local Arab culture. The settlers are tuned towards a different temporal experience, rejecting anything that might negatively affect their fantasy, despite some aesthetic attraction towards what is considered authentic in the Arab landscape.

Possibly, planning authorities devoted insufficient attention to romantic expression in architecture; but, over time, the community's everyday life imposes its unique character on the settlement scenery. Consequently, scarcity of romantic manifestations in it is not solely attributable to preliminary lack of orientation, which raises doubts about the authenticity and

7) Areas of Palestinian self-government.

8) As opposed to the ultra-orthodox. 
relevance of the romantic narrative in the settlers' routine perceptions of nature and landscape. Wherever they make contact with their surroundings, they deliberately ignore undeniable aesthetic values of beauty and everything justifying their ideology and self-sacrifice. The landscape functions as a touchstone and the romantic narrative loses part of its essential vigour in the gap between the perceived and the actual dimensions of the environment and scenery.

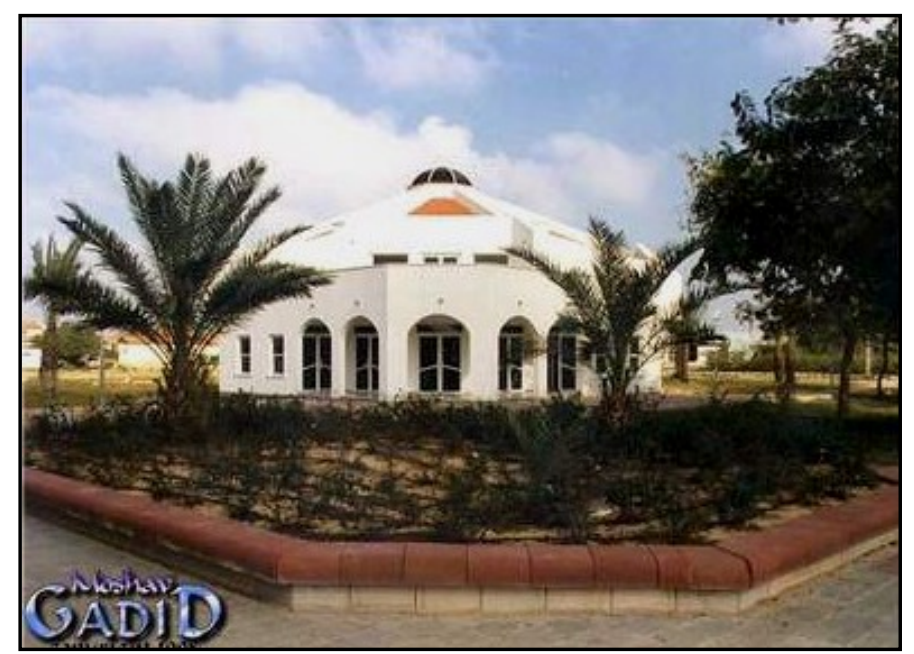

Fig. 2 - The Synagogue in Gadid

\section{The Classic Narrative}

The Wilderness. Gush-Emmunim's principal narrative regarding the new territories is desert reclamation, which reiterates Zionist traditions that Eretz-Israel is part of the global, whiteman's frontier. There, enlightened Israeli civilisation encounters backward Arabs, whose untamed nature must be refined to bring enlightenment and progress (Hasson 1981). The wasteland is antithetical to Jewish construction, development and productivity. In the settlers' narrative today, earlier Zionist symbolism of reclamation, ploughed fields and progressive factories, yields to middle-class criteria of large detached, red-roofed houses and children's playgrounds.

In essence, the settlers' narrative is wasteland eradication. However, reality is more complex than this oversimplification and requires clarification of the term 'wasteland'. The author of 'The Core Issue of Eretz-Israel' in the 'Yesh B'Yesha' anthology writes,

Yesha is under-populated, with only $30 \%$ of the region exploited for building, development or agriculture and the remainder completely wilderness. Anyone travelling along its main or back roads passes bare, rocky, unpopulated hills, finding four Arab and two Jewish villages rather than a possible fifty between Ramallah and Latrun... Eight Arab villages and a growing number of Jewish settlements and townships, including the town of Ariel, are located along the main road crossing Samaria...thus the developing region includes economically backward, under-populated areas... the so-called Arab towns in Yesha are merely small urban communities... Nablus, the largest, is no bigger than one Jerusalem neighbourhood... without traffic lights, 
multi-storied buildings or pay parking... The second largest Israeli industrial park is in the council's district, with 100 factories... in most settlements there are industrial zones with small factories and workshops (Yesh Beyesha 20.3.1987).

With characteristic colonial arrogance the article states that improvement of the local underdevelopment demands modern, progressive resettlement, and implies that what does not represent progress is wasteland and must yield to settlers representing modern forces. Identifying natives' wilderness with cultural inferiority is typical of the classic frontiersmen's approach that considers the natives wild and uncivilised.

A Gush-Emmunim settler provides another dimension of the wilderness. She reports her father's reactions after studying the landscape,

...mountains, low Arab houses, olives, sheep, well...everything is from Genesis... Have you settled here to start from the beginning?" he asked and, taking a hoe, prepared plots by the prefab for vegetables and flowers...

The landscape's meaning and legitimacy of the settlement process appears through her father's eyes. The surroundings reveal primordialism that requires enlightening transformation into plots for vegetables and flowers. She remembered her ancle expressing his hope that a large, dynamic town would evolve. He used to mention in his stories to her the fear and emptiness when riding in convoy with fruit from Galilee via Nablus to Jerusalem in 1931, without one Jewish house for shelter. Emptiness and wilderness have ethnic and religious connotations. Emptiness indicates absence of Jews and Jewish settlement but not of other lifestyles; for the portrayed landscape is not specifically empty countryside. It is packed with evidence of active human presence - water-well, house, olives...During the earlier journey to Jerusalem the travellers' dominant feeling was fear and emptiness; now the settlement process fills the emptiness with the known thus overcoming fear.

The wilderness, meaning Jewish absence, is unacceptable and Jews must settle it. Arabs are uncivilised, part of the surrounding desolation; Jews represent civilisation and are entitled to dominate the wilderness, in its name. An article, 'Thirty minutes from Qiryat Arba'9), explains why the settlers chose the remote location,

The founders visited Harei Hebron, discovered the Jewish settlements' sparse distribution and decided to settle there (A leaflet distributed on 1983).

The only reason for the settlement's location is to eliminate Jewish absence. The Har Hebron regional council Internet site reports,

Alongside the autonomous rural Arab areas are many uninhabited areas awaiting Jewish settlement development.

Recognising the others' presence does not diminish ideological fervour in identifying empty space for settlement, despite changing political realities.

Bird's-eye views of settlements like Migdalim, Othniel and Nahliel reveal alien settlement fortifications in wild, hostile surroundings (Fig. 3). More critical examination reveals that although sited on rocky, uncultivated hills, they are encompassed by cultivated space that has retained its traditional character for hundreds of years; olive terraces fill every scrap of

9) Gush-Emmunim settlement on north-east outskirts of Hebron. 
cultivable land that slopes uphill in the valleys. A peripheral road isolates the settlement from these landscapes that harmoniously integrate with nature. Its approach road cuts abruptly across cultivated terraces and pastureland, linking the settlement with a central road system designed to bypass the Arab villages. At night, powerful, yellowish, automatic floodlights illuminate the Jewish settlement boundary and its roads. The spotlighted hilltops emphasise the gloom of the Palestinian villages, reinforcing the idea of a wilderness awaiting Jewish development.

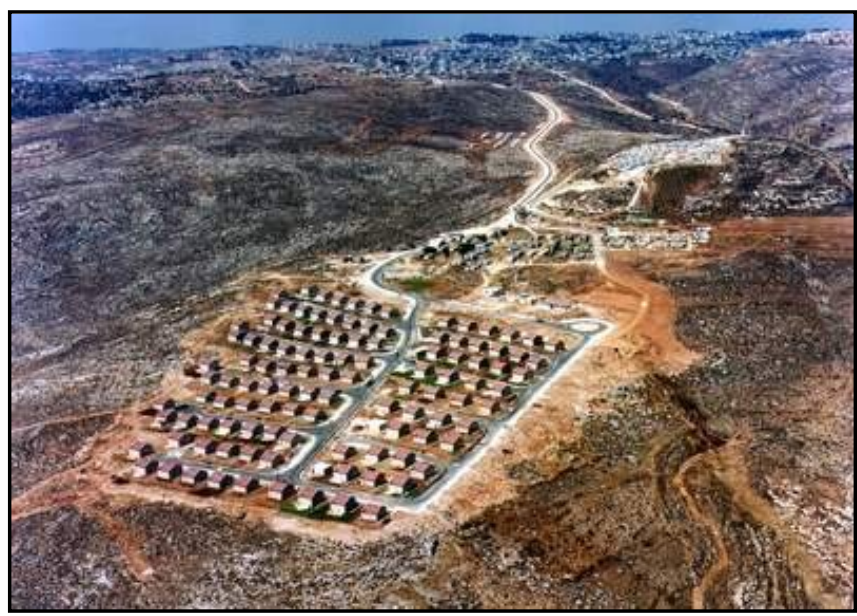

Fig. 3 - A bird eye view of a settlement

Another concept requiring clarification is 'making the wilderness bloom'. In Yesha this means making the countryside green. An article, 'Thus a State gets built', describes Beit Yatir settlement,

At an altitude of $900 \mathrm{~m}$, Beit Yatir overlooks the desert fringe surrounding it. Did I say desert? What about that greenery: woods, orchards, and vineyards? Indeed, the desert is almost eliminated (Ben Pazi 1988).

And another testimony from Beit El supplements the argument:

One sees much greenery in Beit El, lawns, trees and bushes, profusions of flowering roses... eight years ago I worked a full day, before the previous Shmita ${ }^{10)}$, to make the Beit El desert bloom (A leaflet distributed in Beit El 1993).

Lawns, roses and greenery exemplify not necessarily local landscape, but suburban landscape with English free style gardens. The eyes look out of a friendly, green bubble at arid desolation; thus greenery is the ultimate manifestation of desert elimination. The cool, green lawn, reminiscent of earlier domestic scenes, summarises the contradiction between the settlement and its surroundings arid like landscapes. The stretch of lawn and patch of domestic garden cannot easily overcome nature's hostility to become rooted in the scorched environment. Environmental alienation is the consequence. There is an analogy between their relative success and the inescapable challenge of holding on to this specific area.

10) The seventh year in a seven-year cycle, when land in Israel lies fallow and debts are cancelled. 
The settlement's crowdedness and heavy traffic, as the antithesis to the uninhabited surroundings, is the answer to the empty, open spaces.

The following description of Beit Yatir's economic sectors demonstrates the modern productive element in the classic narrative.

This was a godforsaken, intimidating wilderness. Settlers shrunk from everything. It was a tremendous challenge, but we 'took up the gauntlet'...We could overcome the desert, if there were water. Development investments were enormous; economically, the orchards will never justify the cost of the water pipe, but that is how Israel was created...There is no comparison between the Palestinians' life today and under Jordanian rule. Nearly all their Yesha villages have electricity. They have refrigerators, television, piped water, laundry-machines...electricity means women's liberation. Most men speak Hebrew from working for us... One needs time to understand the area's uniqueness concerning field crops. Cotton is reasonably profitable, thanks to new expertise. Although chicken-coops are high-cost state-of-the -art, they are profitable. For three years, I coordinated the sheepfold intensively like an 'industrial crop' with precisely planned expensive fodder and without romance... we worked night and day and made considerable headway. (Ben Pazi 1988).

Overcoming the desolated wilderness is a tremendously challenging mission without benefit or gain, and enlightened occupation has promoted progress among the Palestinians. The account details the agricultural diversity and the partially successful struggle against the uncompromising environment. The settlers have brought progress and expect the Palestinians to be grateful.

Naomi Frankel, an author from Qiryat Arba, writes in a Har Hebron regional council publication intended to encourage young couples to live in its settlements:

Twenty years ago Har Hebron region was unsettled by Jews. The first settlement appeared in 5740 (According to the Jewish calendar, or 1980 according to the Christian calendar) ... now there are fifteen more with diverse lifestyles. All were established to populate the area and reclaim the desert through farming, industry and tourism...now Har Hebron is full of life... the introduction is over but there is much to do, the agenda includes expanding settlements, infrastructure and employment ...developing the educational and cultural system based on instilling values and strengthening settlement roots.

The reality of the landscape narrative in the above is naturally rather superficial. The gap is conspicuous between the absolute wilderness existing twenty years ago and today's blossoming prosperity thanks to fifteen little Jewish settlements; a wilderness suddenly becomes a flourishing garden.

The following manifests a different perspective:

After we passed through Arab villages blending naturally into the hilly landscape, 'Nili' ${ }^{11)}$ seems like Lego houses stuck on the bare mountain. The houses will take root in their land, after trees and greenery surround them. (Ben Pazi 1988).

The author's atypical disapproval implies discomfort at landscape foreignness, despite ideological leanings. However, it turns out that landscape gardening will engender feelings of rootedness, thus achieving desired legitimacy. The next critical quotation should be understood as part of the same worldview:

11) Gush-Emmunim settlement 
We have discarded our swaddling-clothes; there are no more embryonic pioneering settlements...it is not a trivial matter, for the appearance of the settlement and its interior aspect influence visitors - opponents and champions - no less than atmosphere and ideology ....we must improve our landscape gardening (Ben Pazi 1988).

Landscape gardening in the suburban classic English style - lawns, hedges and flowerbeds requires artificial watering. It instils feelings of home and protection against hostile nature. The stability, legitimacy and normalcy that it radiates are important instruments in gaining public support; their absence, displaying impermanence, would encourage political opposition. The essence of the suburban classic outlook is that civilised men transform Creation and design new, natural surroundings for themselves. Like the North American suburban lifestyle obsession to lawns and English style gardening best characterizes the celebration of victory over nature and the celebration of the upper-middle class material achievements. In contrast, uncivilized human beings must adapt themselves and fit their lifestyle to natural forces that they cannot transcend.

The settlers' classic narrative outlines a dynamic approach that spatially transforms a primitive landscape into an advanced one, turning aridity into greenness and replacing backwardness with progress and prosperity. The suburban landscapes in the narrative indicate estrangement from the natural and romantic environment that was the domain of the Patriarchs' fabulous deeds. Its reasoning demands comprehensive planning and control over future developments. Specialists steer regional development plans with the avowed purpose of strengthening Jewish settlement. Projects are instituted to improve the infrastructure and reduce friction with Palestinians. These include bypasses and 'secure bridges', and professional and technological education, constructing industrial parks and developing 'telecommuting' to replace commuting, promoting advanced farming and developing picturesque sites and tourism. This will continue the illusion of spatial wastes devoid of Arabs. Palestinians, who were expected to welcome progress brought by the settlers in the 1980s, are excluded from the dream of regional prosperity in the 2000s. Their presence is perceived as obstructing development. Development and prosperity are directed exclusively to settlers and achievable only if denied to Palestinians.

\section{Landscape conquest - Israelising the Landscape}

This section deals with an exceptionally sensitive political aspect of the settlers' activities in nature, namely, their efforts to 'Israelise' it. The pioneers' attitude is that their activities are within the context of the national, religious and ethnic conflict with the Palestinians, in a zero-sum game where only one of the two sides can be present. Dismissing the 'other' and emphasising everything expressing 'Israeliness' are part of this. The following illustrates this by referring to published statements and by describing the architecture, layout and surroundings of various settlements and buildings.

The Neve Dekalim Yeshivat Hesder ${ }^{12)}$ is a prominent three-storied structure, sited at the edge of the settlement close to the Neve-Dekalim industrial park, adjacent to Khan-Yunis ${ }^{13)}$. Standing out in the sensitive border area between Khan-Yunis and Neve Dekalim, it seems to send a belligerent message of national defiance.

The Nahal-Oz ${ }^{14)}$ roadblock seems briefly the boundary of sanity, on the other side,

12) Combined army service and Judaic studies program of the Israeli army.

13) A Palestinian township in the Gaza strip.

14) Israeli kibbutz bordering the Gaza strip. 
madness and fear. When I ask the longhaired reservists whether I am on the right road, before I say where, they reply with conviction, "No!" ... an electronic fence induces fear, and invisible signs shout, "Enemy territory." ....after one and half kilometres, a gate in the fence, a yellow roadblock, a watchtower and soldiers... "Don't stand so exposed! ... Don't forget the apparent peacefulness is deceptive." Even a flock of sheep approaching the fence increases tension... finger firm on the trigger-guard. Seven minutes drive into the Palestinian Autonomy. Jeep leading, two following, and I feel quite safe. But, oddly, somehow all the passing scenery reveals only tree-trunks broken into strange angles, twisted chunks of rusty metal that were once something else and some new automobiles, that earlier had other owners... (M. Dolev, Nekudah 183).

The drive to Netzarim reveals 'invisible signs' that increase alienation, threat and panic; fences, roadblocks, watchtowers, allegedly 'security elements', somehow arouse fear. The barrier they create changes from functionally separating territories with different political status to isolating the writer's familiar world of sanity and enlightenment from the other alien, savage one.

Two photographs, 'Palestinian landscape viewed across rocks blocking the approach road to Palestinian Tekoah.' and 'the surroundings of Pesagot', illustrate the same dissociating alienation. Concrete walls, fences, and watchtowers protect the settlers, who see the other landscape across these segregating systems.

\section{A similar experience is described in 'Sabbath in Gush-Qatif'}

We drew near the Kissufim roadblock, leaving Israel as we rapidly passed the eucalyptus grove. Approaching the roadblock became more and more like an unavoidable clash with a truck. We saw a brown structure; not grey like the sky or brown like the land, but grey as iron and brown as muddy mortar... I gazed along the roadside wanting to stare at our murderers ... instead of former trees and groves; muddy fields churned by armoured tracks extend, with Mirkavah tanks seemingly stuck fast in the mud. Concrete walls appear from nowhere, and soldiers loaded with protective wear blink through the concertina wire ... Cubes of concrete replace the uprooted eucalyptuses, dividing the road into Jewish and Arab sides. Do Israel lovers uproot trees so readily? Muddy fields, overcast skies, scattered heavy weaponry together made the place like a battlefield ... (Nekudah 239).

The roadblock is an unofficial boundary. The area beyond it is not perceived as Israel and has been denuded by the army. The hostile landscape transformation upsets the observer and raises doubts about a love of Eretz-Israel that is accompanied by landscape destruction. A Gush-Qatif settler returning from central Israel passes through menacing roadblocks and ruined wasteland before reaching Gush-Qatif. On the way to the hothouses, the settlers negotiate four different types of fence and roadblock around Gaza-Strip, Gush-Qatif, the settlement and the hothouses. These obstacles segregate civilized settlers from bewildered Palestinians. Beside the alienation and fear resulting from the multiplicity of defensive measures dispersed in the countryside, the disparity in lifestyle appearing in the disorder, litter, neglect, wear and lawlessness stolen vehicles - add to the menace and disquiet.

Three of Shmuel Moshannik's paintings illustrate the local landscape. His scenery is not idyllic; marked anxiety, nervous suspense, unease and emotional upheaval all emerge through the superficial pastoral simplicity. In one painting, a skull-capped Jew 
contemplates the facing view, evidently of Arab space. It is an intense blue complex, with scores of windows like wide-open eyes, a hostile location projecting an aggressive, harassing aura. The artist explains that beside man's personality, which the painting expresses independent of time or space, there are also moods that time and space do create.

In the two other paintings, the artist presents ancient, timeworn, stone structures that proclaim emptiness, the setting for ancient or future events, which are not necessarily blessings - the bloody clashes of 1929 or Armageddon? The arena of events is oriental and lacks 'players'. Moshannik paints the Hebron scene without people. The buildings seem charged with evil. The town square is empty, awaiting its new inhabitants. Human activity is depicted as though it does not belong to the Hebron scenario and even damages it and would be appropriate for the artist to ignore. In a third painting, the intense colouring seems to express a messianic-apocalyptic, warlike event, a presentiment of judgement day, the end of the familiar world and beginning of something new. The menacing and alarming attraction of ancient structures may reflect frustration that the land of our forefathers is full of Arabs. This might explain the absence of people compared with the massive permanence of the buildings; at least eternity is Jewish. The alien, menacing scene that Moshannik paints is reminiscent of the previous quotations.

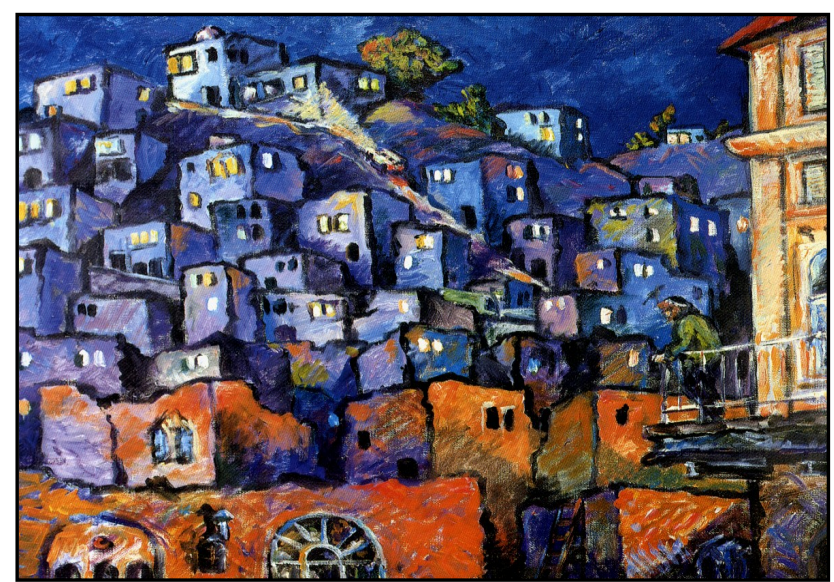

Fig. 4 - Shmuel Moshannik, The pioneer in the alien town of Hebron

Sensations of hostility and alienation transmitted from unfamiliar landscapes are eliminated by introducing into it elements of familiar traditional landscape. The Jewish settlements are conspicuous for their incompatibility with their surroundings. This contributes to the contest over the landscape's character, when confronting the traditional Palestinian landscape that one must continue to conquer.

From a bird's eye view, specifically when passing above our area at night, one sees light that was absent twenty years ago. One can hardly discern Arab villages - at most a few isolated spots of light. However, one can't miss Jewish settlements. Circles of orange light in a sea of darkness; circle after circle, we reach light again (Droma 9). 
The Jewish landscape is deliberately designed to be different from the traditional local landscape - eye-catching in contrast with the easily ignored, unlighted Palestinian landscape. The intention is to overcome darkness and illuminate everything. The consequence is an orderly landscape based architecturally on the suburban model of the coastal-plain, which Architect Zvi Sheftler reviews disapprovingly, below.

The settlement planning was systematic; without exception modelled on Savion ${ }^{15)}$ - road networks, matching shop-fronts, standard parcelling, row upon row of small plots, on some much bigger houses than the original Savion - consequently, mini-Savion and maxi-ma'abarah $^{16)}$ (Nekuda 1985, 13).

Thus the night landscape was composed of one continuous carpet of bright lights distributed along the top of the crests merging with the intensive lights of the coastal plains within the green line. In between some dim lights in the valleys encroached of the Jewish lighted space.

The layout of Qatif, west of Khan Yunis, demonstrates the dissociation between the two landscapes. Four hundred metres separate the settlement from the Palestinian town, but the real distance is much greater. Primarily, Qatif faces west. This is climatically logical but also underlines an attitude regarding the neighbouring Arab town. Agricultural areas with hothouses, sunscreens, large, sophisticated dairy-barns and a completely new chicken-coop without chickens physically separate the two. These areas slope gently down towards Khan-Yunis. Looking towards the settlement from Khan-Yunis, one first sees the agribusiness areas. Beyond them in the distance stands a fence with concrete panels against light weapons; farther on, can be distinguished the acute-angled, red-tiled roofs of settlement's houses. These face westwards and lack any eye contact with the neighbouring town. This seems to illustrate the planners' desired relations with the neighbours. The settlement is built with a rectangular road network linking its two long sides. The original, modest houses usually without well-cared gardens have been renovated to appear like typical of Israeli villas, with red, acute-angled roofs, projecting windows and white, aluminium shutters. The enlarged lofts under raised roofs hide sun-heated water-tanks and can be turned into spare rooms. The gardens here add to the English style, Mediterranean elements rooted in the history of early Zionist landscapes - lemon cypresses and here and there with beds of tropical plants, well stocked with coco-palms and philodendra; extensive green lawns waste water ubiquitously in private and public gardens, resulting in typical Israeli confusion. In general, despite the settlements' infancy and the immense importance their advocates ascribe to their existence, no real attempt is made to fashion an aesthetic architecture. On the contrary, the attempt is to construct an Israeli form of western suburbia.

\section{Conclusions}

The settlements' landscapes as the materialization of settlers' discourses emphasize the tensions between romanticized nationalist neo-Zionist vision and the attempt to symbolize the superiority of Jewish 'civilized' discourse over native savage reality. Like in suburban places they include a strong preference to private houses and gardens. Like other Israeli houses they are designed in terms of eclectic dreams of villas in places outside the region. Beyond the eclecticism they are influenced by Mediterranean Toscana styles including classical elements. Gardens are based on wide lawns and European trees being inspired by English free style gardens and at times decorated by sub-tropic vegetation that hints at early Zionist landscapes.

15) A socio-economically top-level dormitory community near Tel-Aviv.

16) Temporary camps established for new immigrants at Israel's inception. 
These landscapes are alien to the local nature and the Palestinian landscapes while they are originated in the local Mediterranean climate. Even some kitsch decorations that hint at the acceptance of local culture that frequently decorate Israeli houses, are absent from the settlers' private houses (Amir 2007). Above all several testimonies stress the importance of English style gardens that influenced Israeli gardens in general, play an essential role in creating in the settlers' mind sense of home place escaping the sense of wilderness.
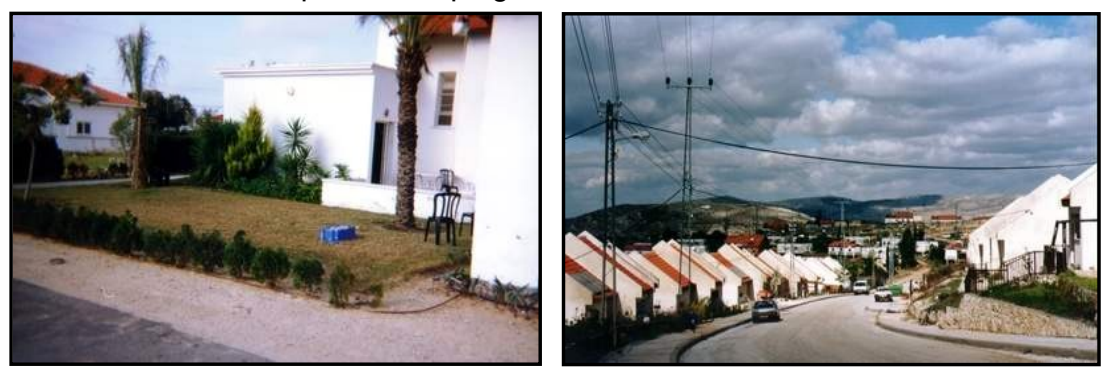

\section{Fig. 5 - A typical settlement suburban landscape}

The settlements remain small knit homogeneous communities rich with religious institutions in a way that stress the middle class values of individualism and self expression in the home as ones castle as well as the communal life based on religious lifestyle. But being located as small islands of civilization in an ocean of savage nature and Palestinian natives, they need to fortify their settlements. Sense of place and home can be achieved only once the settlement's landscape is characterized by the imposition of the aforementioned civilized landscape as the advertisement to the settlement of Livne demonstrates. The loans, the red roof houses, the family and the community all are symbolized in the picture (Fig. 6).

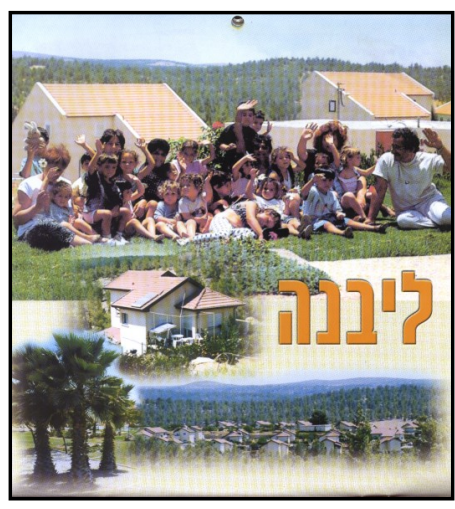

Fig. 6 - Advertising the settlement of Livne

The imposition of Israeli landscape, alien to local nature and Palestinian material culture, the strategic location of the settlements on hilltops and their fortification in respect to the open, modest Palestinian landscapes that integrate in local nature symbolizes uneven power relations that characterize colonial landscapes as William J. Mitchel puts it (2006). This landscape best represents the settlers lived worldview as it is represented in the aforementioned image of nightscapes that actually and symbolically unite lighted (and enlighten) sceneries of settlements with the lights of Israeli cities down along the coastal planes and in contrast to the darkness of the Palestinian nightscapes. A confrontational landscape in Nezarim presents additional example. The religious building in the shape of the Zionist symbol 'David Shield' reigns the surrounding covered by endless carpets of Chan Yunes' refugee camp seen on the horizons beyond the fence surrounding the settlement.

\section{References}

AMIR, T. (2007), The frozen time in residential houses: A Toscana and Provence Villa, in Sheli, C., Amir, T. (Eds.) Residential forms: architecture and society in Israel, Am Oved: Tel Aviv. 
ANDERSON, B. (1991), Imagined Communities, Vers, London.

ANDERSON, M. (1997), Frontiers, Malden, Policy Press.

ARAN, G. (1986), From Religious Zionism to Zionist religion: Roots of Gush-Emmunim culture, Ph.D. Dissertation, Hebrew University, Jerusalem.

BEN PAZI, R. (1988), Returning to the beginning, Beit-El Library.

BIGER, G. (1997), Jewish colonization in Eretz-Israel - the colonial model, Mifne June, pp. 59-60.

BRODY, H. (1983), Maps and Dreams, Pantheon Books, New York.

CRONON, W. (1999), A place for stories: nature history and narrative, in Buttimer, A. and Wallin, L. (Eds.) Nature and Identity in Cross-Cultural Perspective, Dordrecht, Kluwer, pp.201-234.

DAVIDSON, K. (2006), Designing a walk able suburban landscape, Master thesis, Blacksbury, Virginia.

DE-SHALIT, A. (1995), From the political to the objective: the dialectics of Zionism and the environment, Environmental Politics, 4,1, pp. 70-87.

DIJKINK, G. (1996), National Identity and Geopolitical Vision, London, Routledge.

DREPER, M. (1998), Zen and Art of Garden Province Maintenance: The Soft Intimacy of Hard Men in the Wilderness of Kwazulu-Natal, South Africa, 1952-1997, Journal of South African Studies, 24,4, pp.801-828.

FIEGE, M. (1999), Judea and Samaria are "Here", Occupied Territories are there: Scientific Practices and the Formation of Space in Israel, Theory and Critique, 14, pp. 25-39.

FIEGE, M. (2002), Two Maps for the West Bank: Gush-Emmunim and Peace Now and the Formation of Israeli Space, Eshkolot Library, Hebrew University, Jerusalem.

GALILI, A. (1993), The museum in Yifat, Naor, M. (Ed.) The Jezreel Valley, Jerusalem, Yad Ben Zevi Publisher, pp. 253-262.

GORNEY, Y. (1966), The romantic aspect in the second wave immigrants' ideology,

Asufot, 1, pp.55-74. GUREVITZ, Z. (2007), On Israeli and Jewish Place, Am Oved, Tel Aviv.

HASSON, S. (1981), From frontier to periphery, The Land of Israel - Research in the Land Knowledge and its Antiquity, 22, pp. 85-94.

HIRSCHFELD, A. (1989), What does light without a viewer? Mshkafayim, 7, Jerusalem, Israeli Museum Press.

HOOKS, B. (1991), Yearning, Race, Gender and Cultural Politics, London, Turnaround. JENKINS,V. S. (1994), The Lawn: A History of an American obsession, Smithonian Institution Press, Washingon.

KEMP, A. (1991), Spatial Nationality: The Labour Party Controversy on Territories and Borders, MA Thesis, Sociology Dep. Tel Aviv University. KIMMERLING, B. (1983), Zionism and Territory, Berkeley, University of California Press.

LETER, A. (2002), Colonial Settlers and the Metropole:Radical Discourse in Early $19^{\text {th }}$ Century Cape Colony, Australia and New Zeland, Landscape-Research, 27,1, pp. 39-49. LIGHT, A. (1995), The Metaphorical drift of classical wilderness, Geography Research

Forum, 15, pp.14-32.

MARCHENT, C. (1995), Reinventing Eden, in Cronon, W. (Ed.) Uncommon Graund,

Toward Reinventing Nature, New-York, Norton, pp. 133-143.

MITCHEL, D. (1994), Landscape and surplus value: The making of the ordinary in

Brentwood, California, Environment and Planning D, Society and Space, 12, 7, pp. 7-30. NAULA, C. J. (2000), Modern Historical Geographies, Pearson Educational Limited, pp. 251-269.

MITCHEL, W.J.T. (2006), Christo's gatesand Gillo's walls, Critical inquiry, 32, pp. 23-47. NEWMAN, D. (1985), The Impact of Gush-Emmunim Politics and Settlements in the 
West Bank, London, Croom Helm.

NEWMAN, D. (2001), From National to Post-national Territorial Identities in IsraelPalestine, Geojournal, 53,3, pp. 235-246.

PASSI, A. (1999), Nationalizing Everyday Life: Individual and Collective Identities as Practice and Discourse, Geographic Research Form, 19, pp. 4-22.

PLOSZAJKA, T. (2000), Historiographies of Geograpies and Empire, in Graham and Catherine, Modern Historical Geographies, Pearson Education Limited, pp.121-142.

PORAT, H. (1988), My search for Anat, Beit-El Library.

RAVITZKI, A. (1998), The Land of Israel in Modern Thought, Jerusalem, Yad Ben-Zevi. SCHAMA, S. (1995), Landscape and Memory, Vintage, New York.

SCHEIN, R. (1997), The place of landscape: A conceptual framework for interpreting the American landscape, Annals of the Association of American Geographers, 87, 4, pp. $660-680$.

SCHNELL, I. (1997), Nature and Environment in the socialist-Zionist pioneers, Ecumene, 4,1, pp. 69-85.

SCHNELL, I. (1998), Transformations in the myth of the inner valleys as a Zionist place, in Light, A. and Smith, J. M., Philosophy and Geography 3, New York, Rowman \& Littlefield Publisher, pp. 97-116.

SCHNELL, I. (2000), Les representations de Tel Aviv dans l'art Sioniste, Geographie et Cultures, 36, pp. 87-106.

SCHNELL, I. (2011), Geographical Ramifications of the Occupation on Israeli Society, in Bar-tal, D., Schnell, I. (Eds.), The Impacts of the Occupation on Israeli Society, Oxford University Press, New York.

SCHWARTZ, D. (1996), Belief on an Intersection, Tel Aviv, Am Oved.

Beit El.

SHAFAT, G. (1995), Gush-Emmunim: Behind the Screen Story, Beit-El Publisher:

SHAPIRA, A. (1992), The Pigeon Sward, Tel Aviv, Am-Oved.

SIBLEY, D. (1995), Geographies of Exclusions, London, Routledge.

SINHA, A. (1995), Introduction: Varieties of Nature Viewing in Sinha Amita (ed), Landscape Perception, London, Academic Press.

SIVAN, A. (1991), The Culture of the enclave, Alpayim, 4, pp. 45-98. New York.

SPRINZAK, E. (1991), The Ascendance of Israeli Radical Right, Croom Helm,

TURNER, F. J. (1963), The Significance of the Frontier in American History, Edited by Simonson H. P. NewYork, Ungar.

Initial submission, July 5, 2011

Revised submission, Octomber 1, 2011

Final acceptance, November 30, 2011

Correspondence: Geography and Human Environment Department, Tel Aviv University, P.O.B. 39040 Israel 69978

E-mail: schnell@post.tau.ac.il 
